\title{
Impacts of supplemental irrigation as a climate change adaptation strategy for maize production: a case of the Eastern Cape Province of South Africa
}

\author{
S Ndhleve ${ }^{1 *}$, MDV Nakin ${ }^{1}$ and B Longo-Mbenza' \\ 'Risk \& Vulnerability Assessment Centre, Walter Sisulu University, Nelson Mandela Drive Campus, Private Bag X1, Mthatha, 5100, South Africa
}

\begin{abstract}
Dry spells and climatic hazards are responsible for maize output decline, sometimes to levels below potential yield levels. There is a pressing need to reduce the gap between actual and potential maize yield/ha, especially among farmers in semi-arid regions. This present study examines the potential role of supplemental irrigation and its differential impact on maize yield in the Eastern Cape Province of South Africa. In this study, maize yield data were generated from information recorded over a period of 20 years by farmers in Ntabankulu through cross-sectional interviews with 124 randomly-selected farming households. Maize yields for interviewed farmers were analysed for each of the experienced climatic hazards, for yield decline per ha and preferable adaptation strategies. Maize yield analyses show a maximum ceiling/attainable yield of $0.234 \mathrm{t} / \mathrm{ha}$ and average farm yield of $0.146 \mathrm{t} / \mathrm{ha}$. Floods or hailstorms cause $75 \%$ decline in maize yield/ha and there was no significant difference between farmers practising irrigation and those practising dryland farming $(P>0.05)$. Low/no rains throughout the season; delay or low onset of rainfall and a rain-break for a week or more in a season results in $75 \% ; 54 \%$ and $50.5 \%$ decline in maize yield/ha, respectively. On a scale of 1 to 10 , farmers highly rank practicing supplementary irrigation (8.4) and change of planting date (7.8) as important adaptation strategies. Rescheduling planting date from the traditional planting times to earlier or later planting dates, assisted by use of weather reports and forecasting, to some extent curbs the impact of delays or slow onset of rainfall on yield. Supplemental irrigation is instrumental in reducing the impact of midseason drought (rains break for a week) and light rainfall throughout the season. Analyses of actual yields and yield decline against each of the experienced climatic hazards provided insight into management possibilities to stabilize maize output.
\end{abstract}

Keywords: agronomic practices, climatic hazards, supplemental irrigation, semi-arid areas

\section{INTRODUCTION}

Climate change continues to be discussed globally and research reveals rising evidence of the phenomenon with increasing climate change-associated developmental challenges (Cooper et al., 2008; IPCC, 2014). Work done by the Intergovernmental Panel on Climate Change (IPCC, 2001, 2007, 2014) cumulatively reveals evidence to confirm that livelihoods are increasingly becoming vulnerable to the risks posed by climate change. Crop yields are sensitive to changes in rainfall and temperature patterns. Warmer temperatures tend to boost yields when complemented with enough rainfall. While acknowledging that climate change is a global phenomenon, the IPCC (2007) argues that climate change vulnerability and its impacts are projected to be highest in the tropics and sub-tropics, sub-Saharan Africa included. Crop farming is dependent on climate and climate change plays a key role in farmers' livelihoods. It is the poor and farming communities with limited adaptive capacity that are most susceptible to changes in climate. Thus, for the farming communities, climate change continues to be a determinant of survival and human livelihoods.

Rainfall and temperature patterns and climate in general have been changing over the past decades in Africa. Each of the past 3 decades has been successively warmer than any preceding decade since 1850 (IPCC, 2014). The IPCC (2014) report builds on similar findings by many in sub-Saharan Africa. Sub-Saharan

*To whom all correspondence should be addressed.

e-mail: ndhleve@gmail.com

Received 14 April 2016; accepted in revised form 3 March 2017
Africa has experienced a warming trend, with temperatures having risen by over $0.5^{\circ} \mathrm{C}$ over the last 100 years (Smit et al., 2000; Archer et al., 2010; Chishakwe, 2010), the sub-Saharan Africa region has experienced rising temperatures, a downward trend in rainfall, droughts and warming up of the Indian Ocean during the same period. Similar results were also reported at a more local geographical scale. Akpalu et al. (2008) reported that temperatures in South Africa increased by $0.13^{\circ} \mathrm{C}$ between 1960 and 2003, and projected further changes in rainfall and temperature. Variations in climate pose a significant threat to crop production and ultimately food security (Nhemachena and Hassan, 2007). The observed changes in climate are affecting crop yields differently in many regions, particularly within subSaharan Africa (Akpalu et al., 2008; Blignaut et al., 2009; Meza and Silva, 2009; Cairns et al., 2012). Rain-fed farming systems are the dominant source of staple food production and the livelihood foundation of the majority of the poor in sub-Saharan Africa, where investment in irrigation systems is low and scarce (Cooper et al., 2008). Limited and/or absence of irrigation in sub-Saharan Africa's agricultural sector makes the sector highly sensitive to continued climatic hazards (Cooper et al., 2008). The IPCC (2014) noted that vulnerability to climate change and the capacity for adaptation and mitigation for each agro-ecological zone depends strongly on the type of livelihoods, lifestyles, behaviour and culture. Livelihoods depending on climatesensitive sectors or resources are obviously more vulnerable to climate change than their counterparts. The ultimate effect of this vulnerability is widespread food insecurity.

Farming in semi-arid South Africa is predominantly practised under rain-fed conditions and hence fundamentally dependent on the vagaries of weather. As climate change is 
increasingly becoming a threat to farming, real concerns emerge over it. The challenge of how to cope with dry spells, short periods of water stress during crop growth, remains largely unsolved (Oweis and Hachum, 2006). There are many technologies to improve water productivity and the management of scarce water resources. Among the most promising, supplemental irrigation is one of the proven efficient technologies (Oweis and Hachum, 2006). According to Oweis and Hachum (2006) supplemental irrigation is defined as the addition of limited amounts of water to essentially rain-fed crops, in order to improve and stabilize yields during times when rainfall fails to provide sufficient moisture for normal plant growth and, therefore, to minimise the adverse effects of soil moisture stress on the yield of rain-fed crops during dry spells.

For many households, farming is hopelessly unproductive as it fails to meet even the 'subsistence needs', let alone provide any surplus to sell. In South Africa, for instance, the average farm sizes are shrinking and in many cases reduced to homestead gardens. Maize yields are reportedly averaging less that $0.5 \mathrm{t} /$ ha (Fanadzo et al., 2010). Average annual household income remains low while statistics suggest that the average farmer is currently a net buyer of agricultural produce (Hebinck and Van Averbeke, 2007). In South Africa, Bundy (1988) and Mafeje (1988) have argued that rural farmers were once successful and were producing surplus for the markets. Bundy (1988) argues that farmers were once very successful in producing a wide variety of crops, including maize and vegetables, and further links the current food insecurity to climate variability. Low maize yields, and the food insecurity that is currently impacting rural farming communities of South Africa, are argued to be linked to climate variability (Bundy, 1988; Mafeje, 1988). Harrison et al., 2011), however, posited that the identification of major types of climatic stressors affecting different cropping systems provides a foundation upon which crop production and adaptation strategies can begin to be prioritised in order to attain food security. The present study was therefore undertaken to examine the potential role of supplemental irrigation in improving yields in the Eastern Cape, especially the communal farming systems. Understanding adaptation practices pursued by farmers and their capacity to reduce maize yield loss could be fundamental, and can facilitate climate change resilience on the basis of community-driven approaches.

\section{STUDY AREA AND METHODOLOGY}

This study was conducted in 5 wards of the eastern region of South Africa, in Ntabankulu Local Municipality, Eastern Cape Province. The region has both arid and semi-arid climate zones, with mean annual rainfall and temperature ranging from $550-700 \mathrm{~mm}$ and $24.5-25^{\circ} \mathrm{C}$, respectively, and is currently experiencing changes in climate. From 1970 to 2006, rainfall and temperature have decreased by $4.8 \%$ and $2.8 \%$, respectively (Blignaut et al., 2009). Projections for future climatic changes in the region suggest changes in both rainfall and temperature (Akpalu et al., 2008). The economy of these communities depends heavily on agriculture. Low crop yields due to climate change are currently starting to be significant problems in the study area. This area was once one of the major food production areas in South Africa.

Data for this study were collected through a survey conducted in Ntabankulu Local Municipality, using a structured questionnaire and maize yield records as the main instruments. The sample consisted of 124 randomly-selected farming households. The questionnaire encompassed demographic, household socio-economic information, agricultural systems and maize yield levels under different climatic conditions. Data on crop management and adversities were collected from a subset of 123 field-years through survey questionnaires and personal interviews. Information on maize yield and incidence of crop adversities was based on farmers' visual inspection and records. Questions relating to agronomic practices used to curb the impact of climate change on maize were also comprehensively captured in the questionnaire.

Yield potential $\left(Y_{\mathrm{p}}\right)$, defined as the yield of a crop cultivar or hybrid when grown under non-limiting abiotic and biotic conditions, is a factor of genotype, plant population density and uniformity, and location-specific factors (Grassinia et al., 2010). Yield potential was obtained from information on seed packets

\begin{tabular}{|l|c|c|c|}
\hline \multicolumn{2}{|c|}{ TABLE 1 } \\
\hline Characteristics & All respondents & Dryland farmers & Irrigating farmers \\
\hline Household size & Mean (SD) 6 & $\begin{array}{c}\text { Mean (SD) } \\
6.47(2.7)\end{array}$ & Mean (SD) \\
\hline & $N$ & $\%$ & $3.7)$ \\
\hline Age of head of household: & & & 62.5 \\
$<$ <0 years & 8 & 37.5 & 33.7 \\
30-50 years & 82 & 66.3 & 31.4 \\
$>$ 60 years & 34 & 68.6 & 46.8 \\
\hline Gender: & & & 36.2 \\
Male & 79 & 50.6 & 24.5 \\
Female & 47 & 63.8 & 48.9 \\
\hline Education: & & & 58.3 \\
Not educated & 49 & 75.5 & 25 \\
Primary education & 45 & 51.1 & 37.5 \\
Secondary education & 24 & 41.7 & 31.3 \\
Tertiary education & 8 & 75 & 0 \\
\hline Marital status: & & & 36 \\
Married & 64 & 62.5 & \\
Single & 32 & 68.7 & \\
Divorced & 4 & 64 & \\
Widowed & 25 & & \\
\hline
\end{tabular}




\begin{tabular}{|l|c|c|c|c|c|}
\hline \multicolumn{7}{|c|}{ Number of farming households and farming systems practised } \\
\hline \multirow{2}{*}{ Farming system } & Ward 4 & Ward 5 & Ward 6 & Ward 13 & Ward 14 \\
\cline { 2 - 6 } & $\mathrm{N}$ & $\mathrm{N}$ & $\mathrm{N}$ & $\mathrm{N}$ & $\mathrm{N}$ \\
\hline Dryland farmers & 25 & 12 & 14 & 9 & 7 \\
\hline Irrigated agriculture & 2 & 2 & 11 & 19 & 15 \\
\hline Crop & $\mathbf{( \% )}$ & $\mathbf{( \% )}$ & $\mathbf{( \% )}$ & $\mathbf{( \% )}$ & $\mathbf{( \% )}$ \\
\hline Beetroot & 18.8 & 0 & 4 & 3.6 & 4.5 \\
\hline Spinach & 29.6 & 20 & 53 & 60.7 & 50 \\
\hline Cabbage & 25.9 & 6.67 & 56 & 60.7 & 54.5 \\
\hline Potatoes & 25.9 & 21.4 & 36 & 87.7 & 50 \\
\hline Carrot & 14.8 & 0 & 4 & 50 & 9.1 \\
\hline Maize & 66.7 & 46.7 & & & \\
\hline
\end{tabular}

prepared by seed producers. Lack of data from well-designed experiments in which yield-limiting factors have been effectively controlled makes it difficult to obtain reliable quantifications of $Y_{\mathrm{p}}$ based on actual measurements (Duvick and Cassman, 1999). Yield gap analysis was employed to examine differences in maize yield potential, average maximum yield and average yield, between farmers practising supplemental irrigation and those practising dryland farming (Pinnschmidt et al., 1997; Fischer et al., 2009; Fanadzo et al., 2010; Van Ittersum et al., 2012).

The study synthesised statistics on maize yield, yield decline for each climatic hazard recorded, and ranking of the role of each identified adaptation strategy. The ranking system was used to assess the perceived effect of different agronomic practices in reducing maize yield losses as perceived by farmers. The weighting was on a scale of 0 to 10 , where a 0 indicates low importance and 10 high importance of the factor.

\section{RESULTS AND DISCUSSION}

Table 1 provides the socio-demographic characteristics of the sampled households. They are stratified according to their farming operations.

Females dominate the farming community as few males participate in farming. These results also support the finding by Statistics South Africa (SSA, 2012) that female-headed households are more likely than male-headed households to be involved in agriculture. This statistic is higher than the provincial statistic of $37 \%$ published by Statistics South Africa (SSA, 2012). The age distribution of all of the household heads indicates that the majority of them are in the age group 30-60 years $(66.1 \%)$. The aged (above 60 years) account for $27.4 \%$ and the youth account for an insignificant proportion $(6.5 \%)$ of the respondents. The sample population's age distribution shows vast experience with both climatic risks and farming, as experience is approximated by age (Di Falco and Veronesi, 2013). The educational status of the respondents indicates that $37.7 \%$ of the respondents are found to be illiterate. However, the remaining $62.4 \%$ achieved a certain level of education. Out of the $62.4 \%$, $26.8 \%$ are farmers with recognised experience in practising farming in the region. The more experienced and educated households are more likely to be aware of climate risks and to understand their impact on farming activities than the illiterate (Mandleni and Anim, 2011)

Of the survey participants, $62 \%$ practise supplemental irrigation farming or have access to irrigation facilities, either in the form of tap water, rivers or streams, and crop fields or small garden.

\section{Farming system and types of crops grown}

Farming plots in the study area exist as small patches of land, gardens, usually located next to the homestead, and large tracts of land ranging from 0.5 to 15 ha sometimes located far away from the homestead.

Mixed vegetable gardening is a common practice. Maize, spinach and cabbage are the most preferred crops in Ntabankulu. Farmers cited resistance to both diseases and climate variability as the reason for preferring these crops. The other significant but minor crops grown by farmers in Ntabankulu were potatoes, beetroot, and carrots (Table 2).

Farmers are shifting towards both disease and droughtresistant crops and vegetables, thus a low crop mix. The above finding with regard to preferred crops illustrates key links between climate change, plant diseases and food security. Low garden crop or vegetable mix has direct implications for dietary diversity, a proxy for food security. The promotion of farming and crop production in the study area should undertake an integrated approach, where both climate change impacts and incidence of crop disease should be addressed as problems that co-exist.

\section{Maize yield decline}

The observed maize yield results (Fig. 1) show a maximum attainable yield of $0.235 \mathrm{t} / \mathrm{ha}$, average farm yield of $0.146 \mathrm{t} / \mathrm{ha}$ and average climate-limited yield of $0.057 \mathrm{t} / \mathrm{ha}$. Ntabankulu's maize yields are presently far below the potential levels of $3.0 \mathrm{t} /$ ha found by Fanadzo et al. (2010). Low maize yields have a direct impact on food security in the study area. Rapid changes in basic farming practices are necessary, especially when considering the additional strain upon the already low average annual household income reported in the area.

Farm abandonment was widely reported by most respondents. Low maize yield, even below the subsistence level, could be contributing to low interest in farming. Hebinck and Van Averbeke (2007) link farm abandonment to low yields and thus low interest in farming, since farmers are not getting sustainable returns from their farming practices. Low maize yields and abandonment of farming have important implications for food security and livelihoods of the investigated communities. The results were, however, not different from previous studies undertaken in the region. Similar findings were reported by Briceno-Garmendia et al. (2008); Blignaut et al. (2008) and Fanadzo et al. (2010). These results and previous findings identify an important need for knowledge on variables, 


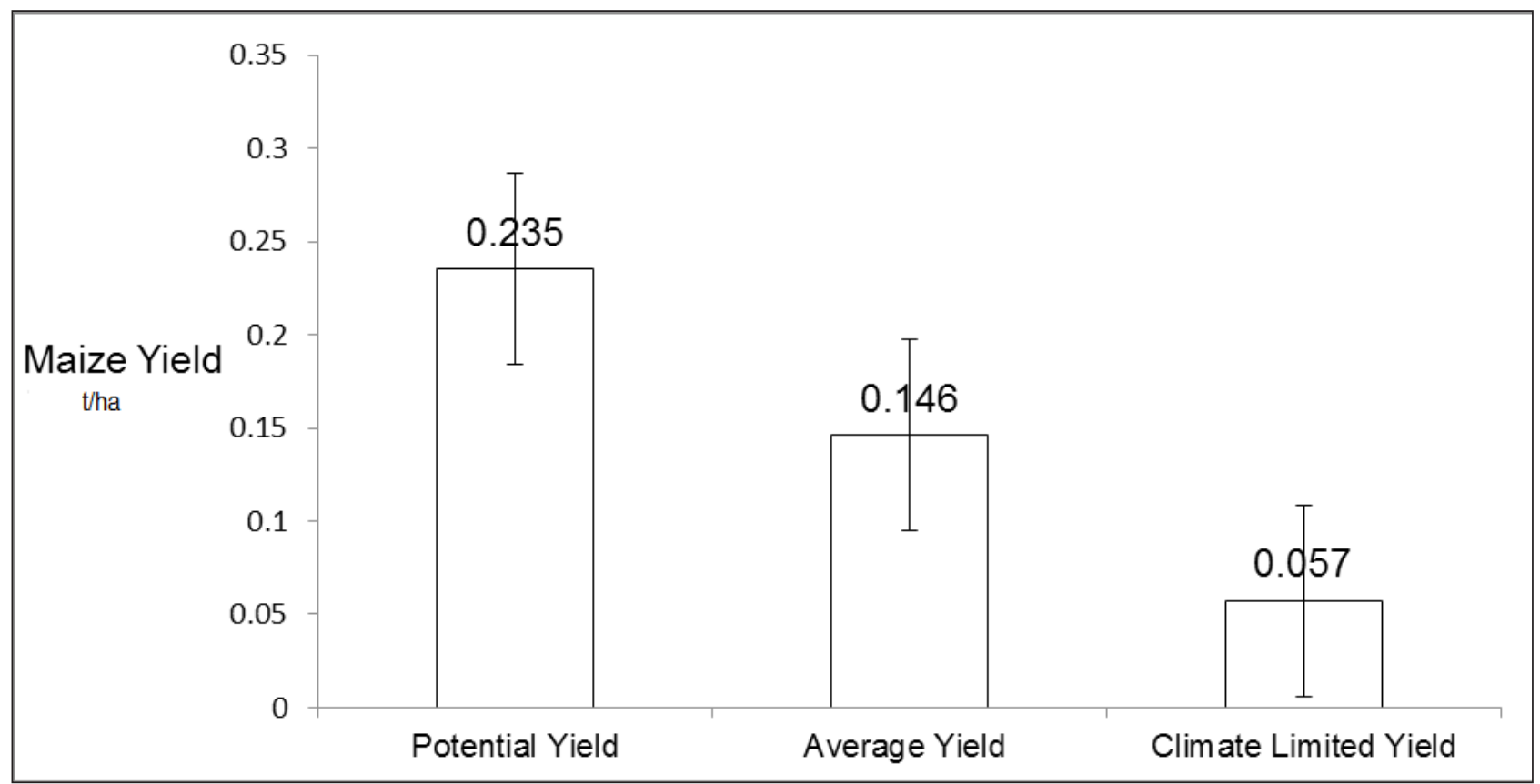

Figure 1

Maize yield (t/ha) across the sampled households

be they biophysical, cultural or socioeconomic, affecting maize farming in the region. Identification and development of appropriate intervention measures to stimulate maize yield to potential production level and to reduce yield losses cannot be overemphasised in the area.

\section{Irrigators and non-irrigators maize yield}

A relatively low proportion of households practise supplemental irrigation (35.4\%) as compared to dryland farming (64.5\%). However, an important finding emerges as $7.6 \%$ of the farmers with access to suitable irrigation infrastructure opt not to irrigate their maize in spite of water stress. They were unenthusiastic about practising supplemental irrigation of their maize and they expressed that they do not see the productive value of irrigating maize and prefer to irrigate other vegetables. It emerged that farmers' knowledge from previous experience with maize causes them to perceive maize as a dryland crop not appropriate for irrigation.

Unlike the conventional thinking, there was no significance difference between average attainable yield (AY), climate-limited yield, average farm yield and average fall in yield (\%), between farmers practising supplemental irrigation and those practising dry-land farming, irrespective of type of irrigation and water source. Reliance on climate-dependent sources of irrigation water could be contributing to similar yield losses between the irrigators and non-irrigators (Table 3). Insignificant differences between observed maize yield statistics could also be explained by the fact that farmers lack basic irrigation skills such as irrigation scheduling and the amount of irrigation water required for optimal maize production, as observed by Sinyolo et al. (2014).

The principal sources of irrigation water, in terms of frequency, were rivers and small streams, followed by municipal water. These are all climate-dependent sources of water, thus likely to be unreliable as climate change impacts. Unreliable irrigation water sources and high dependence on rainfall makes farmers practising irrigation and those farming under rainfed systems non-differentially vulnerable to climate change. Dryland farmers should be targeted for adaptive capacity building programmes because of their vulnerability and proportion in the agricultural economy of many rural areas. Promoting irrigation could to some extent reduce the burden of climate variability (Sinyolo et al., 2014). Use of rainwater harvesting techniques and moisture conservation techniques will reduce the incidence of crop waster stress. Technologies and skills, that would enable local people to directly harvest rainwater and tap underground water and manage these sources effectively, at household or subvillage community levels, have been commended in semi-arid environments, where there is increasing variability of rainfall amount and pattern.

\section{Maize climatic hazard analyses}

Farmers have identified various forms of climatic hazards influential to maize yield, as well as their approximate impacts. Following climatic risks, the interviewed farmers reported that average maize yields decline by between $70 \%$ and $83 \%$, and there was no significant difference in both yield loss and average yield between farmers practising irrigation and those practising rainfed farming. Low maize yields that are far below the potential yield per hectare, and high percentage of yield loss per farmer (averaging 76.5\%), evidently show that maize farming cannot be relied upon as a livelihood activity in the region. The threats to food security are significant, as climate change is expected to be likely to increase the incidence of various climatic risks. Thus, climate change is expected to make it more difficult for maize farmers to catch up with potential crop production in the long run. The challenge for the farmers is to reduce maize yield loss under ongoing climatic variations and thus be food secure.

A unanimous opinion was shared by farmers that unreliable climatic conditions are negatively affecting maize production. Six major manifestations of maize crop climatic hazards have been identified (Fig. 2). Out of the 6 climatic hazards listed, 5 
appeared to be most important in determining maize yield losses in 1 season.

The most devastating climatic hazard as perceived by nonirrigating farmers is the mid-season drought. A rain break of 1 week is reported as likely to reduce maize yield by $50.5 \%$.

Different rankings were noted with regard to each climatic hazard between farmers practising irrigation and those practising dryland farming. Predictably, dryland farmers are the most at risk as their emphasis for yield loss was placed on almost all of the factors (Table 4), with the ones related to the amount and frequency of rainfall highly ranked. Although reported to be low in frequency, farmers practising irrigation and those practising farming under dryland condition emphasised that hail and no rains cause high yield decline. However, those practising irrigation have low concern for all of the other factors. There was no significant difference $(P>0.05)$ between farmers practising irrigation and dryland farmers' rankings of hail/floods and 'no rain at all' as crucial climatic hazards in determining maize yield loss. However, the least important climatic hazards for farmers practising irrigation were light rainfall throughout the year and mid-season drought. The nature of climate variability, if documented, will assist farmers in understanding the impact of climate change on communal farming systems. Farmers understand their environment and the prevailing climatic risks and the significance of perceived rankings of different maize climatic hazards should be considered important, especially when formulating intervention strategies.

\section{Adaptation strategies considered by farmers to reduce yield loss}

Farmers respond to some of the climatic hazards identified here with adjustment or changes in agronomic practices. Unanimous agreement on climate change effects on maize yield was met with a different mix of probable adaptation strategies. The investigated farmers show that they are practising a set of different agronomic practices to reduce yield loss as a result of climate variability. Table 5 shows the factors ranked by the respondents as important in reducing yield loss.

Practicing irrigation and change of planting date emerged as adaptation practices perceived as important in the investigated communities. Farmers noted that rescheduling the planting date, from the traditional planting times to planting dates assisted by use of weather reports and forecasting, curbs the impact of delays or slow onset of rainfall.

Most of the investigated communities are prone to floods and hail. No appropriate adaptation response was perceived to be appropriate as a response to floods and hail. Reduction of farming on steep slopes or erosion-prone areas as an appropriate adaptation response was lowly ranked probably because of limited choice with regard to the location of their fields. It is therefore assumed that the practised adaptation practices are not explicitly applicable throughout the spectrum of all the shocks experienced. Farmers are seemingly more reactive to shocks and adaptive responses that are not capital intensive.

An important theme emerged as farmers from similar agro-ecological settings, strongly assumed to be experiencing similar climatic shocks, surprisingly ranked similar agronomic practices differently. Seemingly, farmers hold different perceptions with regard to each adaptation strategy. Supporting this notion, Deressa et al. (2009) argued that adaptation options

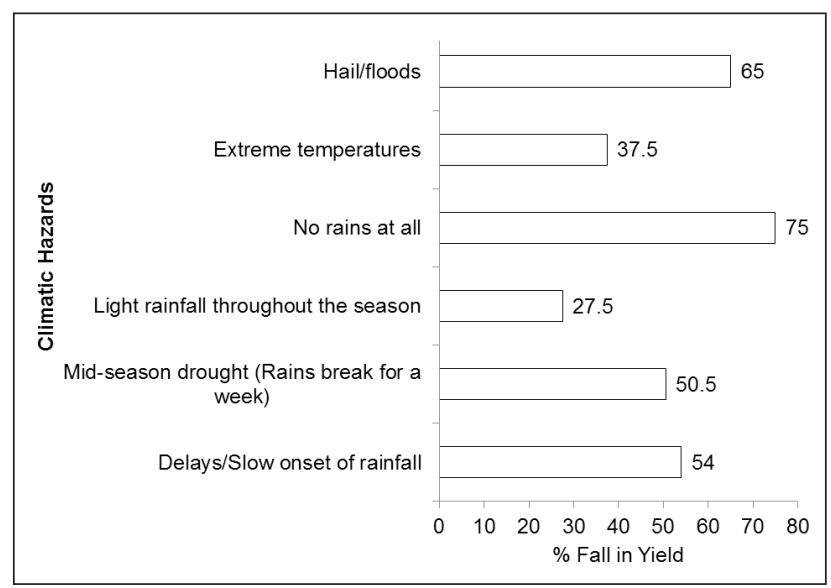

Figure 2

Climatic hazards and their impact on maize yields

TABLE 3

Differences between Irrigators and non-irrigators maize yield (t/ha)

\begin{tabular}{|l|c|c|}
\hline Yield & $\begin{array}{c}\text { Dryland } \\
\text { farmers }\end{array}$ & Irrigators \\
\hline $\begin{array}{l}\text { Average maximum attainable yield } \\
\text { (t/ha) }\end{array}$ & $0.073^{\mathrm{a}}$ & $0.18^{\mathrm{a}}$ \\
\hline Climate-limited yield (PYc) (t/ha) & $0.037^{\mathrm{a}}$ & $0.102^{\mathrm{a}}$ \\
\hline Average farm yield(t/ha) & $0.048^{\mathrm{a}}$ & $0.144^{\mathrm{a}}$ \\
\hline Average fall in yield (t/ha) & $0.0635^{\mathrm{a}}$ & $0.158^{\mathrm{a}}$ \\
\hline
\end{tabular}

${ }^{a}$ Figures in the same row with similar superscripts are not significantly different at $p<0.05$

\begin{tabular}{|l|c|c|}
\hline \multicolumn{3}{|c|}{ TABLE 4 } \\
\multirow{2}{*}{ Climatic hazard } & \multicolumn{2}{|c|}{ Average scores for reasons for fall in maize yield } \\
\cline { 2 - 3 } & Dryland farmers & Irrigation farmers \\
\hline Delays/slow onset of rainfall & $3.97 \pm 0.235^{\mathrm{a}}$ & $4.77 \pm 0.546^{\mathrm{a}}$ \\
\hline Mid-season drought (rains break for a week) & $7.06 \pm 0.339^{\mathrm{a}}$ & $2.06 \pm 0.124^{\mathrm{b}}$ \\
\hline Light rainfall throughout the season & $6.10 \pm 0.191^{\mathrm{a}}$ & $3.12 \pm 0.084^{\mathrm{b}}$ \\
\hline No rains at all & $9.043 \pm 0.103^{\mathrm{a}}$ & $9.780 \pm 0.004^{\mathrm{a}}$ \\
\hline Extreme temperatures & $8.02 \pm 0.008^{\mathrm{a}}$ & $5.13 \pm 0.003^{\mathrm{b}}$ \\
\hline Hail/floods & $9.22 \pm 0.253^{\mathrm{a}}$ & $7.09 \pm 0.234^{\mathrm{a}}$ \\
\hline
\end{tabular}

${ }^{a b}$ Rankings in the same row with different superscripts are significantly different at $P<0.05$.

${ }^{a}$ Rankings in the same row with similar superscripts are not significantly different at $P<0.05$.

The higher the value the more important the hazard. 
TABLE 5

Agronomic practices considered to be important by farmers in Ntabankulu, Eastern Cape

\begin{tabular}{|l|c|c|c|}
\hline Agronomic practices & Irrigators & Dryland farmers & Mean ranks \\
\hline Planting of crop with early rainfall & $3.5 \pm 0.45$ & $9.4 \pm 0.56$ & 6.5 \\
\hline Change of planting date & $8.3 \pm 0.12$ & $7.3 \pm 0.78$ & 7.8 \\
\hline Practice irrigation & $7.8 \pm 0.25$ & $8.9 \pm 0.35$ & 8.4 \\
\hline Use of weather-resistant varieties & $3.5 \pm 0.63$ & $5.6 \pm 0.27$ & 4.6 \\
\hline Listening to weather forecasting & $3.6 \pm 0.37$ & $7.9 \pm 0.33$ & 5.8 \\
\hline Changing the timing of land preparation & $6.7 \pm 0.43$ & $8.7 \pm 0.54$ & 7.7 \\
\hline Reducing farming on erosion-prone areas & $1.2 \pm 0.56$ & $2.5 \pm 0.47$ & 1.9 \\
\hline
\end{tabular}

are influenced by various socio-economic factors; thus farmers look into the multiple interacting factors that may shape the outcome of each adaptation option. However, there are factors that commonly appear to exacerbate adaptation practices, like farming experience, education, capital and access to water.

The studied farmers practise primitive low-value adaptive agronomic practices. No mention was made of important agro-environmental factors like soil moisture preservation and use of existing and emerging crop varieties. Insufficient support, through either research that directly supports the smallholder farmers' operations or appropriate adaptation policies, results in limited or lack of scientifically tested yield loss reducing strategies for the smallholder farmers. Evidently, the studied farmers still have limited options in terms of aligning or changing their production decisions in response to climate variability. The impacts of climatic variability on maize would rather have to be reduced by appropriate moisture management practices and important technologies like adopting weatherresistant varieties.

The studied farmers highlight important reflections for adaptation to climate change. Strong links can be drawn between the identified climatic hazards and agronomic practices considered important by farmers. This suggests that climate change is introducing new and substantial trends in farming practices among communal farmers. Importantly, although not perfect, farmers have commonly-used as well as their own mechanisms for dealing with climatic shocks. Adaptation initiatives and policies by the government and other agencies should understand that farmers have inherent knowledge of climate change that should not be compromised. Their actions and support should build on these practices. Meza and Silva (2009) have stated that farmers sometimes gather enough information before adopting different management practices. An appropriate approach could involve a search of the right mix of agronomic practices and the exercise should be done with the help of local farmers. The exercise will conventionally result in adaptation strategies that are rich in local content and planned in conjunction with the local people (Nyong et al., 2007).

\section{CONCLUSION}

The study argued that practising supplemental irrigation should be coupled with the appropriate agronomic practices for it to successfully reduce yield loss. The consequent level of yield loss by studied farmers is in most cases determined by their perceptions towards a certain agronomic practice, the type of risk and their ultimate understanding of their farming environment. It is recommended that such interactions be increasingly incorporated into climate change outreach programmes with regard to maize farming, with special attention given to dryland farmers. The significance of various agronomic practices depends largely on integrating the emerging scientific knowledge and indigenous knowledge systems.

\section{ACKNOWLEDGEMENTS}

The authors gratefully acknowledge DST/NRF for financing the research activities and Walter Sisulu University's Risk and Vulnerability Science Centre for providing enumerators and transport during data collection.

\section{REFERENCES}

ARCHER DR, FORSYTHE N, FOWLER HJ and SHAH SM (2010) Sustainability of water resources management in the Indus Basin under changing climatic and socio economic conditions. Hydrol. Earth Syst. Sci. 14 (8) 1669-1680. https://doi.org/10.5194/ hess-14-1669-2010

AKPALU WR, HASSAN and RINGLER C (2008) Climate variability and maize yield in South Africa. Environment and Production Technology Division. IFPRI Paper 843. International Food Policy Research Institute, New Delhi.

BARRIOS S, BERTINELLI L and STROBL E (2006) Climatic change and rural-urban migration: The case of sub-Saharan Africa. J. Urban Econ. 60 (3) 357-371. https://doi.org/10.1016/j.jue.2006.04.005

BEMBRIDGE TJ (1984) A systems approach study of agricultural development problems in Transkei. PhD thesis, Stellenbosch University.

BLIGNAUT J, UECKERMANN L and ARONSON J (2009) Agriculture production's sensitivity to changes in climate in South Africa. S. Afr. J. Sci. 105 (1-2) 61-68. https://doi.org/10.1590/ s0038-23532009000100022

BRICEÑO-GARMENDIA C, SMITS K and FOSTER V (2008) Financing public infrastructure in sub-Saharan Africa: Patterns and emerging issues. Background Paper 15. The International Bank for Reconstruction and Development/The World Bank, Washington D.C.

BUNDY C (1988) The Rise and Fall of the South African Peasantry. David Philip, Cape Town.

CAIRNS JE, SONDER K, ZAIDI PH, VERHULST N, MAHUKU G, BABU R and PRASANNA BM (2012) Maize production in a changing climate: impacts, adaptation, and mitigation strategies. $A d v$. Agron. 114 (1) https://doi.org/10.1016/B978-0-12-394275-3.00006-7.

CHISHAKWE NE (2010) Southern Africa Sub-Regional Framework on Climate Change Programmes Report. Draft Working Document, SADC-UNEP (unpublished report).

COOPER PJM, DIMES J, RAO KPC, SHAPIRO B, SHIFERAW B and TWOMLO S (2008) Coping better with current climatic variability in the rain-fed farming systems of sub-Saharan Africa: an essential first step in adapting to future climate change? Agric. Ecosyst. Environ. 126 (1) 24-35. https://doi.org/10.1016/j.agee.2008.01.007

DERESSA TT, HASSAN RM, RINGLER C, ALEMU T and YESUF M (2009) Determinants of farmers' choice of adaptation 
methods to climate change in the Nile Basin of Ethiopia. Glob. Environ. Change 19 (2) 248-255. https://doi.org/10.1016/j. gloenvcha.2009.01.002

DI FALCO S and VERONESI M (2013) How can African agriculture adapt to climate change? A counterfactual analysis from Ethiopia. Land Econ. 89 (4) 743-766. https://doi.org/10.3368/le.89.4.743

DUVICK DN and CASSMAN KG (1999) Post-green revolution trends in yield potential of temperate maize in the North-Central United States. Crop Sci. 39 (1999) 1622-1630.

FANADZO, MC, CHIDUZA PNS, MNKENI I, VAN DER STOEP and STEVENS J (2010) Crop production management practices as a cause for low water productivity at Zanyokwe Irrigation Scheme. Water SA 36 (1) 27-36. https://doi.org/10.4314/wsa.v36i1.50904

FISCHER RA, BYERLEE D and EDMEADES GO (2009) Can technology deliver on the yield challenge to 2050. In Expert Meeting on How to feed the World in 2050. FAO, Rome.

FOSU-MENSAH, BENEDICTA Y, PAUL LG VLEK and MACCARTHY DS (2012) Farmers' perception and adaptation to climate change: a case study of Sekyedumase district in Ghana. Environ. Dev. Sustainability 14 (4) 495-505. https://doi.org/10.1007/ s10668-012-9339-7

GRASSINI P, THORBURN J, BURR C and CASSMAN KG (2011) Highyield irrigated maize in the Western U.S. Corn Belt: I. On-farm yield, yield potential, and impact of agronomic practices. Field Crops Res. 120 (1) 142-150. https://doi.org/10.1016/j.fcr.2010.09.012

HARRISON L, MICHAELSEN J, FUNK C and HUSAK G (2011) Effects of temperature changes on maize production in Mozambique. Clim. Res. 46 (3) 211. https://doi.org/10.3354/cr00979

HEBINCK P and VAN AVERBEKE W (2007) Livelihoods and landscape: people, resources and land use. Livelihoods and Landscape: The People of Guquka and Koloni and Their Resources, Brill Academic Publishers, Boston.

IPCC (2001) Climate Change 2001: The Scientific Basis. Contribution of Working Group I to the Third Assessment Report of the Intergovernmental Panel on Climate Change. Cambridge University Press, New York. 881 pp.

IPCC (2007) Climate Change 2007: The Scientific Basis. Contribution of Working Group I to the Fourth Assessment Report of the Intergovernmental Panel on Climate Change. Cambridge University Press, New York.

IPCC (2014) Climate Change 2014: Working Group II Impacts, Adaptation, and Vulnerability. Cambridge University Press, Cambridge.
MAFEJE A (1988) Culture and development in Africa: The missing link. CODESRIA Bulletin Number 1. . CODESRIA, Dakar Senegal.

MANDLENI B and ANIM FDK (2011) Climate change awareness and decision on adaptation measures by livestock farmers in South Africa. J. Agric. Sci. 3 (3) 258. https://doi.org/10.5539/jas.v3n3p258

MEZA FJ and SILVA D (2009) Dynamic adaptation of maize and wheat production to climate change. Clim. Change 94 (1-2) 143-156. https://doi.org/10.1007/s10584-009-9544-z

NHEMACHENA C and HASSAN R (2007) Micro-level analysis of farmers' adaption to climate change in Southern Africa. International Food Policy Research Institute, New Delhi.

NYONG A, ADESINA F and ELASHA BO (2007) The value of indigenous knowledge in climate change mitigation and adaptation strategies in the African Sahel. Mitigation Adaptation Strat. Glob. Change 12 (5) 787-797. https://doi.org/10.1007/s11027-007-9099-0

OWEIS T and HACHUM A (2006) Water harvesting and supplemental irrigation for improved water productivity of dry farming systems in West Asia and North Africa. Agric. Water Manage. 80 (1) 57-73. https://doi.org/10.1016/j.agwat.2005.07.004

PINNSCHMIDT HO, CHAMARERK V, CABULISAN N, DELA PEÑA F, LONG ND, SAVARY S, KLEIN-GEBBINCK HW and TENG PS (1997) Yield gap analysis of rain-fed lowland systems to guide rice crop and pest management. In: Kropff MJ, Teng PS, Aggarwal PK, Bouma J, Bouman BAM, Jones JW and Van Laar HH (eds.) Applications of Systems Approaches at the Field Level, Volume 2. Kluwer Academic Publishers, Dordrecht.

SINYOLO S, MUDHARA M and WALE E (2014) The impact of smallholder irrigation on household welfare: The case of Tugela Ferry irrigation scheme in KwaZulu-Natal, South Africa. Water SA 40 (1) 145-156. https://doi.org/10.4314/wsa.v40i1.18

SMIT B, BURTON B, KLEIN RJT and WANDEL J (2000) An anatomy of adaptation to climate change and variability. Clim. Change 45 (1) 223-251.

TOLLENAAR M and LEE EA (2002). Yield potential, yield stability and stress tolerance in maize. Field Crops Res. 75 (2) 161-169. https://doi. org/10.1016/S0378-4290(02)00024-2

VANITTERSUM MK, CASSMAN KG, GRASSINI P, WOLF J, TITTONELL P and HOCHMAN Z (2012) Yield gap analysis with local to global relevance-A review. Field Crops Res. 143 (1) 4-7.

WOLF JI, ALLICE I and BELL T (2013) Values, climate change, and implications for adaptation: Evidence from two communities in Labrador, Canada. Glob. Environ. Change 23 (2) 548-562. https://doi. org/10.1016/j.gloenvcha.2012.11.007 